\title{
Analisis Kebijakan Pembangunan Industri Berbasis Aglomerasi (Kawasan) Industri
}

\author{
Ade Faisal ${ }^{1}$ \\ Ministry of National Development Planning/Bappenas - Indonesia
}

\begin{abstract}
Abstraksi
Pertumbuhan sektor industri non migas di Indonesia cenderung mengalami penurunan pada beberapa tahun terakhir (BPS, 2017), termasuk proporsinya terhadap total Produk Domestik Bruto (PDB). Terkait hal tersebut, program utama Pemerintah yang menjadi flagship untuk pembangunan industri adalah pengembangan 14 kawasan industri prioritas di luar pulau Jawa (Bappenas, 2015), dengan pertimbangan untuk pemerataan pembangunan industri sekaligus meningkatkan populasi industri besar dan sedang yang jumlahnya juga cenderung stagnan dalam beberapa tahun terakhir (BPS, 2017). Namun kebijakan ini belum didukung oleh persiapan dan perencanaan yang matang, yang dibuktikan dengan kurang berkembangnya hampir seluruh KIP yang ada. Kemudian pembangunan KIP sendiri merupakan proyek jangka menengah-panjang yang tidak langsung terlihat hasilnya dalam jangka pendek sehingga kontradiktif dengan penetapan target pertumbuhan industri tahunan yang mencapai 5-6 \% (RPJMN 2015-2019). Untuk itu, dilakukan analisis pembangunan industri berbasis kawasan yang bergerak dari pendekatan fundamental dari sisi pelaku usaha, yaitu melalui investasi pabrik baru ataupun ekspansi dari existing business melalui penurunan cost, peningkatan value added, ataupun perluasan pasar yang secara akumulasi mampu memberikan profit maksimal dari sisi bisnis dibandingkan alternatif lainnya. Dengan kata lain Kawasan Industri yang ditetapkan harus mampu memberikan keuntungan bagi pelaku usaha dengan memenuhi pendekatan tersebut. Kemudian beberapa best practice dari sejarah perkembangan KI di beberapa negara juga akan dibahas untuk mengidentifikasi beberapa faktor penting dalam membangun KI. Hasil akhir dari studi ini antara lain merekomendasikan perbaikan pola kebijakan dalam perencanaan pembangunan sektor industri, tahapan-tahapan umum dari pembangunan KI berikut langkah-langkah yang diperlukan terhadap existing KIP yang sedang dibangun, serta mainstream kebijakan yang diperlukan untuk pengembangan industri berbasis kawasan.
\end{abstract}

Kata Kunci: industri, kawasan industri,, tahapan pembangunan, aglomerasi

\footnotetext{
${ }^{1}$ Ade Faisal adalah Kepala Sub Direktorat Ilmu Pengetahuan dan Teknologi di Direktorat Pendidikan Tinggi, IPTEK, dan Kebudayaan, Kementerian Perencanaan Pembangunan Nasional/Bappenas Republik Indonesia. E-mail: ade.faisal@bappenas.go.id
} 


\section{Analisis Kebijakan Pembangunan Industri Berbasis Aglomerasi (Kawasan) Industri}

Ade Faisal

\section{Pendahuluan}

Sektor industri manufaktur adalah salah satu kontributor terbesar terhadap Produk Domestik Bruto (PDB) di Indonesia. Share sektor industri terhadap PDB Indonesia masih merupakan salah satu yang tertinggi di dunia (The World Factbook, Central Intelligence Agency, 2015). Namun berdasarkan data triwulan III 2018, pertumbuhan industri nasional masih tetap berada di bawah angka pertumbuhan ekonomi nasional. Demikian pula kecenderungan penurunan kontribusi (share) sektor industri nasional yang juga masih menurun secara konsisten selama lebih dari 5 tahun terakhir seperti yang terlihat pada gambar berikut ini (Badan Pusat Statistik/BPS, diolah oleh Direktorat Industri, Pariwisata dan Ekonomi Kreatif Badan Perencanaan Pembangunan Nasional dalam 'Manufacturing Sector Review', 2018).

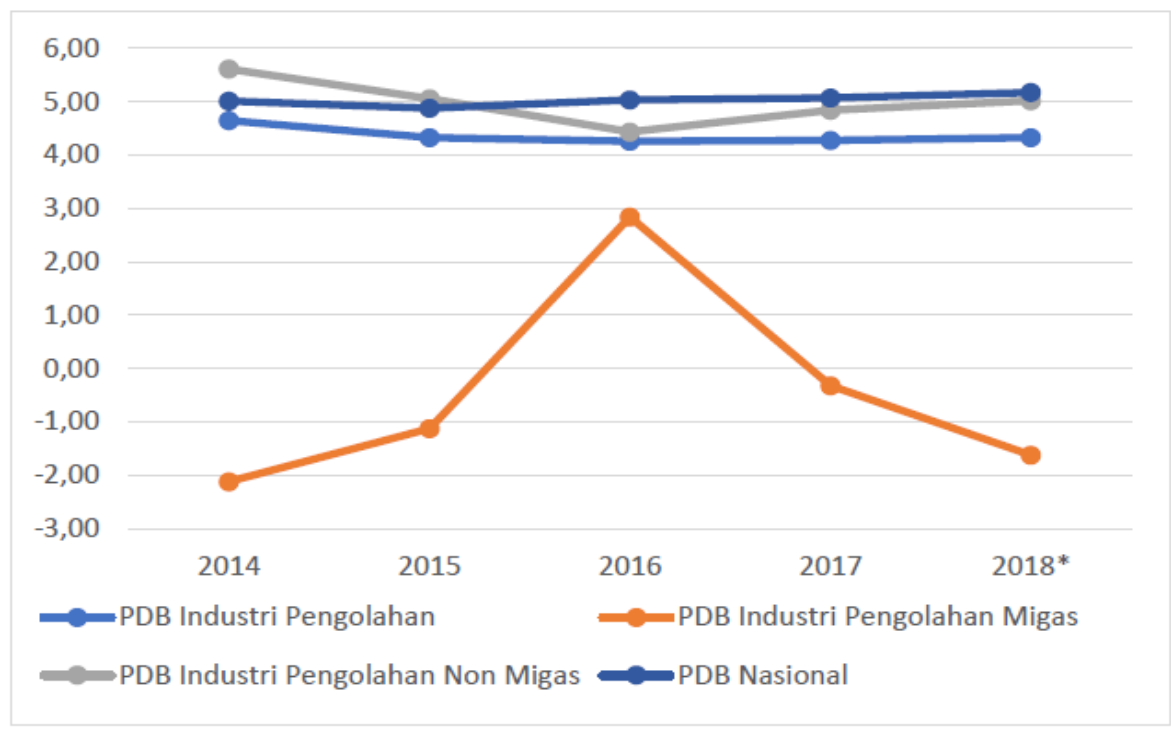

Sumber: BPS, 2018

*Data hingga triwulan III 2018

Apabila kita lihat lebih lanjut, berdasarkan dokumen perencanaan berjalan baik Rencana Pembangunan Jangka Menengah Nasional (RPJMN) 2015-2019 maupun RKP 2018, hingga tahun 2018 program utama Pemerintah yang menjadi flagship untuk pembangunan industri adalah pengembangan 14 kawasan industri prioritas/KIP (Bappenas, 2017) di luar pulau Jawa. Pembangunan 14 KIP ini diprioritaskan dengan pertimbangan untuk pemerataan pembangunan industri sekaligus meningkatkan populasi industri besar dan sedang yang jumlahnya cenderung stagnan dalam beberapa tahun terakhir (BPS, 2018). Hal ini juga merupakan tindak lanjut terhadap salah satu arahan terkait pembangunan sektor industri dalam visi dan misi Pemerintahan Presiden Joko Widodo dan Wakil 
Presiden Jusuf Kalla pada tahun 2014-2019 yang menyebutkan bahwa perlu membangun sekurang-kurangnya 10 kawasan industri (KI) baru. Persebaran 14 kawasan industri prioritas sesuai RPJMN 2015-2019 (Bappenas, 2014) dapat dilihat pada gambar berikut:

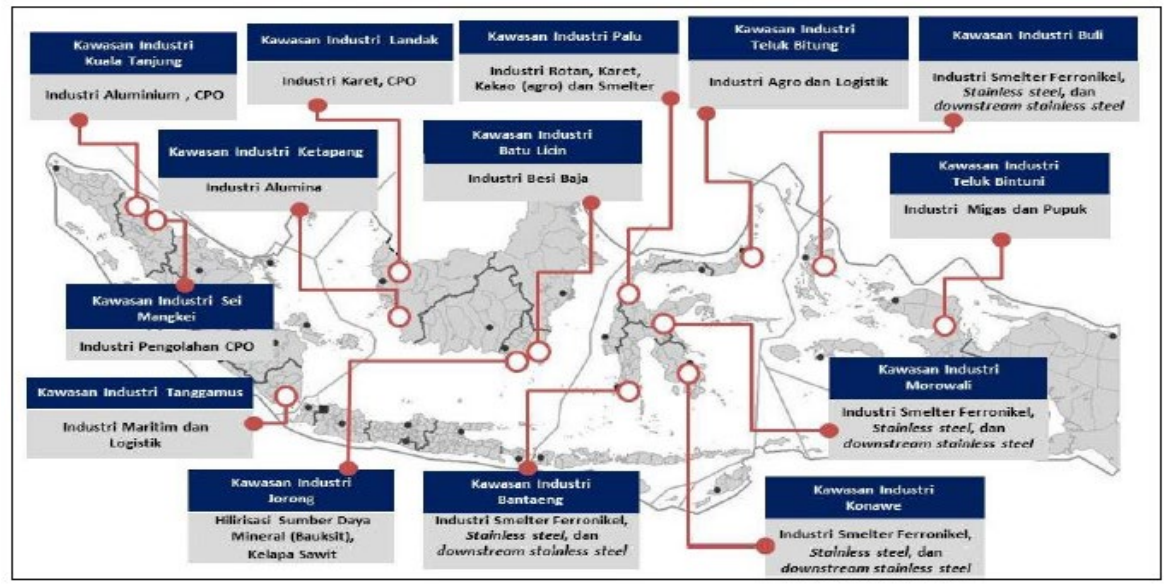

Gambar 1. Kawasan Industri Baru

Sumber: Bappenas, 2014

Namun progres pembangunan keempat belas kawasan industri tersebut berdasarkan evaluasi paruh waktu RPJMN 2015-2019 masih belum sesuai harapan. Sebagian besar dari 14 KIP tidak berjalan dengan lancar dan bahkan masih berkutat di masalah dasar seperti pengelolaan, perizinan, serta pembebasan lahan (Bappenas, 2017). Secara umum yang menjadi akar permasalahan adalah kurangnya minat investor untuk berperan sebagai pengelola ataupun pemilik dari KIP tersebut, karena KIP merupakan suatu kawasan komersial yang profit-oriented. Pengelola dan pemilik di sini harus memiliki kemampuan untuk berinvestasi dalam pengadaan lahan dan operasionalisasi KIP, yang dapat dimulai atau distimulus oleh keberadaan anchor industry yang sejauh ini juga sangat minim peminat yang berkomitmen.

Permasalahan-permasalahan tersebut mestinya bisa dihindari apabila dari sejak awal perencanaan dan persiapan pembangunan KI dilakukan secara matang. Artinya feasibility study atau cost and benefit analysis dilakukan dengan akurat dan melibatkan langsung pelaku usaha serta calon investor. Jadi bukan hanya pekerjaan yang dilakukan dari sudut pandang birokrat ataupun konsultan yang ditunjuk yang seringkali merupakan justifikasi terhadap proyek dan lokasi yang telah ditetapkan sebelumnya. Kemudian pembangunan KIP sendiri merupakan proyek jangka menengah-panjang yang tidak langsung terlihat hasilnya dalam jangka pendek sehingga kontradiktif dengan penetapan target pertumbuhan industri tahunan yang mencapai 5-6 \% (RPJMN 2010-2014). Secara logika juga membangun 14 KIP dari tahapan awal pastinya membutuhkan alokasi anggaran yang sangat besar, sehingga seluruh KIP tersebut tidak mungkin dimiliki ataupun dibangun hanya dengan menggunakan anggaran Pemerintah. Jadi sekali lagi ditekankan bahwa persiapan, perencanaan, dan desain proses bisnis KIP yang akurat dan menarik untuk investor baik investor pengelola, penyedia utilitas, maupun calon anchor/tenant industries merupakan hal yang sangat penting dan merupakan kunci dari keberlanjutan pembangunan dan pengembangan KIP ke depannya. 
Karena itu dalam studi ini dilakukan analisis pembangunan industri berbasis kawasan yang bergerak dari pendekatan fundamental dari sisi pelaku usaha, yaitu pertumbuhan melalui investasi pabrik baru ataupun peningkatan utilitas dan ekspansi dari existing business. Asumsi dasar pendekatan tersebut adalah motivasi perusahaan untuk melakukan ekspansi atau investasi baru adalah untuk memaksimumkan profit. Dalam hal ini maksimum profit dapat diperoleh dari penurunan cost, peningkatan value added, ataupun peningkatan revenue (perluasan pasar) yang secara akumulasi mampu memberikan keuntungan maksimal dari sisi bisnis dibandingkan alternatif lainnya. Apabila dikaitkan dengan pembangunan KI, maka KI yang akan dibangun/dikembangkan harus mampu memberikan keuntungan bagi pelaku usaha dengan memenuhi pendekatan tersebut. Analisis ini juga akan dikaitkan dengan pola kebijakan industri saat ini terutama terkait perencanaan kebijakan dan penyusunan target. Beberapa best practice dari kebijakan industri dan pembangunan KI di beberapa negara juga akan dibahas secara umum untuk mengidentifikasi beberapa faktor penting dalam mengembangkan kebijakan industri dan membangun KI. Hasil akhir dari studi ini antara lain merekomendasikan alur pikir umum dalam perencanaan pembangunan sektor industri, tahapan-tahapan umum dari pembangunan KI berikut langkah-langkah yang diperlukan terhadap existing KI yang sedang dibangun, serta mainstream kebijakan yang diperlukan untuk pengembangan industri berbasis kawasan industri.

\section{Analisis Literatur dan Best Practice Pembangunan KI di Beberapa Negara}

Analisis literatur membahas beberapa isu penting terkait kebijakan industri yang diperoleh dari beberapa referensi termasuk contoh implementasinya di dua negara yang berhasil membangun industrinya dengan karakter yang secara umum masih relevan dengan Indonesia yakni di Korea Selatan dan Taiwan. Kemudian dibahas juga best practice pembangunan KI di beberapa negara yang telah maju industrinya untuk mengidentifikasi faktor-faktor penting dalam pembangunan industri berbasis aglomerasi atau Kawasan industri.

\subsection{Analisis Literatur Terkait Kebijakan Industri 2.1.1. Kebijakan Industri}

Kemajuan sektor industri sebuah negara pasti diikuti dengan kebijakan industri dari Pemerintah negara tersebut yang mendukung perkembangan sektor industri (Rodrik, 2004). Contoh negara yang sukses mengembangkan sektor industri mereka melalui kebijakan industri yang jelas adalah Korea Selatan dan Taiwan. Sejak tahun 1960 Pemerintah kedua negara tersebut fokus untuk mengembangkan sektor industri mereka melalui kebijakan industri yang mampu memfasilitasi perusahaan di sektor manufaktur berkembang dan menggerakkan perekonomian secara keseluruhan.

Rodrik (2004) menyatakan jika tugas dari kebijakan industri adalah untuk mendapatkan informasi dari pelaku usaha yang memiliki eksternalitas yang signifikan, kemudian mengetahui bagaimana cara mengatasi eksternalitas tersebut melalui implementasi kebijakan yang tepat. Implementasi tersebut ditunjukkan dengan kolaborasi yang erat antara Pemerintah dengan pelaku industri dengan tujuan untuk mengatasi hambatan yang ada dan bentuk intervensi yang tepat untuk mengatasi hambatan tersebut. Kebijakan industri yang dihasilkan juga tidak boleh berfokus kepada outcome, melainkan fokus kepada proses penyelesaian hambatan tersebut. 
Tujuan lain dari kebijakan industri adalah untuk mengatasi kegagalan pasar dan institusi dalam suatu perekonomian, terutama di negara berkembang (Lall, 2003). Contoh dari kegagalan tersebut adalah (1) kondisi pasar yang lemah dan tidak konsisten; (2) risiko dari technological spillovers; (3) marketing spillovers dari suatu national brand; (4) returns to scale; (5) kegagalan koordinasi; (6) strategi dalam bernegosiasi dengan negara lain (Stiglitz, 1996).

Menurut Rodrik (2004) kebijakan industri yang mampu mengatasi kegagalan tersebut secara umum mengikuti syarat sebagai berikut:

- Insentif yang dikeluarkan oleh Pemerintah harus ditujukan kepada kegiatan baru.

Menurut Rodrik (2004) salah satu tujuan dari kebijakan industri adalah untuk mendiversifikasi kegiatan ekonomi suatu negara dan menciptakan suatu keunggulan komparatif baru. Oleh karena itu kebijakan industri harus difokuskan untuk kegiatan yang menciptakan produk baru atau kegiatan produksi yang menggunakan teknologi yang baru.

- Indikator yang jelas untuk menentukan kegiatan yang gagal dan sukses

Hal ini diperlukan agar Pemerintah tidak terus memberikan insentif kepada kegiatan yang seharusnya gagal dan agar perusahaan tidak terus meminta insentif kepada Pemerintah. Indikator yang dikeluarkan jangan berfokus kepada output dari kegiatan tersebut. Salah satu indikator yang dapat digunakan adalah kenaikan produktivitas dari kegiatan yang diberi insentif. Selain itu, Pemerintah juga bisa melakukan benchmarking kepada negara lain yang berhasil mengembangkan kegiatan yang sejenis.

- $\quad$ Kesepakatan mengenai sunset close

Sejak awal pemberian intensif dilakukan kepada sektor swasta, Pemerintah harus mampu menetapkan batasan dan syarat terhadap pemberian intensif itu sendiri. Hal tersebut perlu dilakukan agar industri mampu untuk berkembang secara berkelanjutan dan tidak terus menerus mengandalkan insentif dari Pemerintah.

- Fasilitas yang diberikan Pemerintah harus berfokus kepada aktivitas, bukan sektor

Pemerintah tidak memiliki informasi yang sempurna mengenai kondisi seluruh sektor perekonomian di negaranya, sehingga jika Pemerintah harus memberikan fasilitas hanya berfokus kepada sektor tertentu hal tersebut dapat menyebabkan biaya kegagalan yang cukup besar jika sektor tersebut gagal. Fasilitas yang diberikan haruslah berfokus kepada aktivitas yang tidak hanya mendorong perkembangan satu sektor tertentu, melainkan beberapa sektor. Contoh dari fasilitas tersebut adalah pembangunan infrastruktur dan pelatihan tenaga kerja.

Aktivitas yang diberi subsidi oleh Pemerintah haruslah aktivitas yang memiliki potensi spillover terhadap aktivitas lainnya di perekonomian. Contoh spillover yang dimaksudkan adalah menarik investasi di aktivitas yang lain saling berkomplementer atau menciptakan informasi atau teknologi spillover.

- Lembaga yang menjalankan kebijakan industri tersebut haruslah lembaga yang memiliki kompetensi yang tinggi

Jenis lembaga tersebut menentukan jenis insentif yang akan diberikan oleh Pemerintah. Misalkan Pemerintah memiliki dua alternatif insentif untuk 
industri, yakni melalui kredit atau pajak. Jika lembaga keuangan di negara tersebut lebih kompeten, maka lebih baik memberikan insentif bagi sektor industri melalui alokasi kredit. Hal tersebut perlu dilakukan untuk mengurangi potensi kegagalan institusi dari kebijakan industri ini.

- Pengawasan yang ketat dengan outcome yang jelas dari lembaga yang menjalankan kebijakan industri tersebut

Pengawasan tersebut juga sebaiknya dilakukan oleh lembaga yang memiliki kekuasaan politik tertinggi di negara tersebut. Hal tersebut ditujukan agar tidak ada korupsi - yang sangat mungkin terjadi- dalam penerapan kebijakan industri tersebut.

- Menjalankan komunikasi yang baik dan intens dengan sektor swasta

Lembaga yang menjalankan kebijakan industri tersebut memang harus independen untuk mencegah konflik kepentingan yang mungkin terjadi. Namun, hal tersebut tidak berarti tidak ada komunikasi dengan pihak swasta. Salah satu syarat sukses kebijakan industri adalah komunikasi yang baik dengan sektor swasta.

- Jika kebijakan industri yang benar sudah dilakukan, kesalahan dalam memilih aktivitas pasti akan terjadi

Suatu aktivitas yang diberi insentif oleh Pemerintah diharapkan akan mampu memberikan dampak positif bagi perekonomian. Namun, tidak semua aktivitas akan memberikan hasil yang diharapkan dan hal tersebut merupakan hal yang wajar. Kesalahan dalam memilih aktivitas memang akan terjadi, dan hal tersebut bukan berarti suatu kebijakan salah. Dari kegagalan tersebut Pemerintah akan mampu menemukan aktivitas yang benar-benar sesuai dengan perekonomian di negara tersebut dan pada akhirnya mampu mengembangkan perekonomian secara keseluruhan.

- Kebijakan industri harus mampu berkembang seiring dengan berjalannya waktu

Lembaga yang melaksanakan implementasi kebijakan industri tersebut harus mampu terus merevisi dan memperbarui kebijakan industri yang akan dilakukan sesuai dengan perkembangan yang terjadi. Salah satu tugas kunci dari kebijakan industri adalah bagaimana suatu kebijakan industri akan berakhir sementara kebijakan baru diimplementasikan.

Beberapa hal juga harus diperhatikan dalam menyusun kebijakan industri, antara lain : (1) Pemerintah bukanlah aktor ekonomi yang mengetahui segala hal, sehingga setiap kebijakan industri yang dikeluarkan harus berdasarkan kondisi yang diketahui oleh Pemerintah secara pasti; (2) penerapan kebijakan industri sangat mudah terjadi korupsi dan rent-seeking, sehingga lembaga yang menerapkan kebijakan tersebut harus mampu mencari titik keseimbangan antara tingkat independennya dengan seberapa intens komunikasi dengan sektor swasta yang harus dilakukan (Rodrik, 2004); (3) Memasuki abad ke-21, perusahaan-perusahaan manufaktur semakin tidak terintegrasi secara vertikal dan semakin berspesialisasi di teknologi, sehingga kebijakan yang diambil juga harus mempertimbangkan faktor globalisasi yang terjadi (Lall, 2003).

\subsubsection{Best Practices Penerapan Kebijakan Industri: Korea Selatan dan Taiwan}

Menurut Rodrik (1994), keberhasilan Korea Selatan dan Taiwan dalam mengembangkan sektor industrinya bukan disebabkan penerapan kebijakan industri 
yang mendorong ekspor. Melainkan disebabkan oleh kebijakan yang mendorong investasi, baik swasta maupun Pemerintah, serta kondisi awal di Korea Selatan dan Taiwan, yakni sama-sama memiliki angkatan kerja yang memiliki pendidikan yang relatif baik terhadap stok kapital negara tersebut pada waktu yang sama.

Dalam mengembangkan sektor industri di Korea Selatan, Pemerintah Korea Selatan tidak menempatkan dirinya sebagai agen ekonomi yang mengetahui segala informasi dengan sempurna, melainkan sebagai agen mediasi dan fasilitator bagi agen ekonomi lainnya, memastikan informasi beredar secara sempurna, dan memastikan jika tujuan dari setiap kebijakan tercapai. Penempatan posisi Pemerintah Korea Selatan tersebut menyebabkan risiko kegagalan koordinasi menjadi semakin berkurang, yang pada umumnya ditemukan dalam kondisi Pemerintah lainnya.

Sementara itu posisi yang berbeda diambil oleh Pemerintah Taiwan. Pada saat itu Pemerintah Taiwan menyadari jika perkembangan ekonomi melewati beberapa tahap dan pada setiap tahap tersebut jenis industri yang berkembang akan berbeda. Pemerintah Taiwan meyakini jika mereka mengetahui jenis industri yang sesuai dengan tahap tersebut dan kemudian memastikan kebijakan industri yang mereka terapkan mampu untuk mengembangkan jenis industri tersebut.

Meskipun memiliki posisi yang cukup berbeda, namun cara penerapan kebijakan industri yang dilakukan oleh kedua Pemerintahan tersebut sama, yakni berkoordinasi dengan perusahaan-perusahaan manufaktur yang ada di negara tersebut, kemudian mengarahkan keputusan investasi dari perusahaan-perusahaan tersebut kepada sektor yang difokuskan oleh Pemerintah melalui subsidi investasi. Pemerintah Korea Selatan subsidi investasi melalui kebijakan alokasi kredit dan jaminan bagi perusahaan yang berinvestasi di sektor yang sudah ditetapkan, sedangkan Pemerintah Taiwan melalui pemberian insentif perpajakan bagi perusahaan. Kedua cara tersebut memiliki tujuan yang sama, yakni menaikkan nilai return of capital bagi perusahaan agar perusahaan mau melakukan investasi di sektor yang sudah ditetapkan.

Alokasi kredit yang dilakukan oleh Pemerintah Korea Selatan dilakukan dengan memberikan bunga pinjaman negatif kepada perusahaan yang dinilai layak oleh Pemerintah. Syarat kelayakan tersebut antara lain dilihat dari rencana investasi perusahaan tersebut, tingkat penerapan teknologi, keterkaitan dengan perusahaan domestik, dan skala ekonomi perusahaan tersebut. Beberapa kredit khusus juga berikan berdasarkan track record dari perusahaan tersebut, sehingga penerima kredit khusus ini lebih banyak kepada perusahaan yang sudah berjalan.

Kegiatan lain yang dilakukan oleh Pemerintah Korea Selatan dalam memberikan subsidi investasi adalah jaminan kepada perusahaan yang melakukan investasi di kegiatan yang sudah ditetapkan oleh Pemerintah, yang biasanya memiliki risiko yang tinggi, akan di-bailout oleh negara jika mengalami kerugian akibat kondisi yang tidak terprediksi. Contoh dari kegiatan ini adalah Pemerintah Korea Selatan menjamin Hyundai ketika perusahaan tersebut berinvestasi di produksi galangan kapal.

Berbeda dengan Korea Selatan, subsidi investasi oleh Pemerintah Taiwan terletak di pemberian pajak perusahaan yang lebih rendah kepada perusahaan yang mau melakukan investasi di kegiatan yang sudah ditentukan oleh Pemerintah. Pada tahun 1960, pajak pendapatan perusahaan diturunkan dari 32,5 persen menjadi maksimum 18 persen; tax holiday untuk investasi baru dari 3 tahun menjadi 5 tahun; 
pengecualian pajak diberikan kepada perusahaan yang mendahan dividen-nya untuk melakukan reinvestasi; the stamp tax dan deed tax diberikan kepada perusahaan yang produktif dengan pengecualian pajak atau pengurangan pajak; penundaan pembayaran pajak impor untuk plant and equipment hingga setelah beroperasi. Kemudian pada tahun 1965, insentif pajak tersebut diperluas untuk semua sektor prioritas yang terdaftar serta beberapa sektor manufaktur yang spesifik (logam dasar, mesin dan elektronik, alat transportasi; pupuk kimia; petrokimia; dan pipa gas).

Selain memastikan sektor swasta melakukan investasi pada kegiatan atau sektor yang sudah ditentukan, kedua Pemerintahan tersebut juga menjadi pionir dalam melakukan investasi di sektor yang pada awalnya tidak memiliki keuntungan bagi perusahaan swasta- sekalipun sudah diberikan subsidi. Contohnya adalah Pemerintah Taiwan adalah yang pertama berinvestasi di bidang plastik, tekstil, serat, baja, dan elektronik. Sementara di Korea Selatan, setiap diversifikasi industri yang terjadi pada tahun 1960an dan 1970an selalu diawali dari Pemerintah (Amsden, 1989 dalam Rodrik, 1994).

\subsection{Contoh Best Practices Pembangunan KI}

\subsubsection{Definisi Kawasan Industri (Industrial Estate)}

Pengembangan Kawasan Industri menjadi salah satu cara yang digunakan oleh Pemerintah dalam melakukan industrialisasi di negaranya. Dalam hal ini, pengertian Kawasan Industri yang digunakan merujuk kepada pengertian dari industrial estate, yakni:

"An industrial estate is a grouping of industrial establishments provided with certain common services and utilities laid down in advance of demand, and established as a result of enterprise and planning by an independent organization (Bale, 1974)"

Perserikatan Bangsa Bangsa (PBB) (1962) menjelaskan jika ada beberapa hal yang perlu dipersiapkan dalam pembangunan fisik dari suatu kawasan industri, yakni:

- Perencanaan Kawasan Industri

Hal ini perlu dilakukan untuk memastikan kawasan industri yang dibangun bernilai ekonomi, sesuai dengan fungsinya, dan menarik bagi para pelaku industri.

- $\quad$ Transportasi

Penyiapan sarana transportasi yang sesuai dengan karakteristik dari industri yang akan berada dalam kawasan tersebut. Selain mengakomodasi kebutuhan perusahaan yang ada, transportasi untuk karyawan yang akan bekerja di kawasan tersebut juga harus diperhatikan. Karena itu jaringan logistik melalui pelabuhan dan multimoda angkutan barang (jalan, kereta api, transportasi udara) menjadi hal penting berikut akses karyawan ke lokasi Kawasan yang akan dikembangkan.

- $\quad$ Penyediaan Infrastruktur Dasar

Suatu kawasan industri sebaiknya berada di jarak yang cukup dengan infrastruktur publik, seperti air, energi, dan utilitas, atau pengelola kawasan harus mengembangkan sendiri infrastruktur dasar tersebut di dalam Kawasan industri yang dikembangkan. 
- Layout

Dalam penyediaan layout (master plan), dasar yang harus dipertimbangkan adalah supply chain yang meliputi efektivitas dan efisiensi pergerakan barang, orang, dan jaringan utilitas (air, gas, energi, dll). Hal-hal seperti penyediaan lahan parkir dan bongkar muat, ukuran dan cakupan pabrik, serta penyediaan untuk ekspansi di kemudian hari juga menjadi perhatian

- $\quad$ Gedung Pabrik

Kawasan Industri harus mampu menyediakan bangunan dengan harga termurah dan konstruksi yang efektif dan efisien, serta konsisten dengan standar kondisi dan suasana lingkungan bekerja yang baik (keamanan, ketertiban, kebersihan, dan kesehatan)

Selain semua syarat pembangunan fisik kawasan industri tersebut, penyediaan lahan yang diperuntukkan untuk kawasan industri menjadi syarat penting bagi pengembangan suatu kawasan industri, termasuk di Indonesia. Hal tersebut disebabkan masalah ketersediaan lahan sering kali menjadi masalah utama dalam pengembangan kawasan industri di negara berkembang (Fong, 1980). Bahkan, Kim dan Gallent (1997) mengatakan jika Pemerintah harus mengetahui demand forecasting dan supply lahan untuk pengembangan kawasan industri ke depannya.

\subsubsection{Model Pembangunan Kawasan Industri Negara Lain 2.2.2.1. Pengembangan Kawasan Industri Berdasarkan Pelaku: Great Britain}

Pengembangan kawasan industri di Inggris Raya sudah terjadi sejak Revolusi Industri terjadi. Namun sejak perang dunia kedua (setelah tahun 1945), pengembangan Kawasan Industri di Inggris Raya menjadi capaian sendiri bagi Pemerintah Inggris Raya pada saat itu (Bale, 1977). Menurut Norcliffe (1975, dalam Bale, 1977) pemilihan lokasi dari suatu pengembangan Kawasan Industri adalah berdasarkan beberapa faktor, yakni: (1) ketersediaan infrastruktur; (2) economies of scale, baik dalam kawasan ataupun di luar kawasan; (3) pola keterkaitan dan hubungan dari Kawasan Industri tersebut.

Semenjak perang dunia kedua selesai (setelah tahun 1945), terdapat beberapa pergeseran dari pengembangan kawasan industri di Inggris Raya. Beberapa pergeseran tersebut antara lain pemilihan lokasi yang tidak selalu di pusat-pusat kota serta bertambahnya beberapa pelaku yang membangun dan mengembangkan kawasan industri di Inggris. Menurut Bale (1977), pelaku pengembangan kawasan industri di Inggris setelah perang dunia kedua adalah: perusahaan pengembang milik swasta, Pemerintah lokal, dan Pemerintah pusat.

\section{Pengembangan Kawasan Industri Milik Swasta}

Dalam jurnalnya, Bale (1977) membagi perusahaan pengembang milik swasta menjadi dua jenis, yakni perusahaan lokal dan perusahaan nasional. Perusahaan pengembang lokal sebagian besar masih bersifat kecil (dari sisi modal) dan hanya mampu menyediakan satu lokasi untuk pembangunan dan atau pengembangan kawasan industri tanpa mampu menyediakan di tempat lainnya. Selain itu, biasanya para perusahaan lokal ini hanya mengganti nama daerah industri yang sudah ada di daerah tersebut.

Sedangkan perusahaan pengembang swasta yang berskala nasional pada umumnya merupakan perusahaan besar. Pada era sebelum Perang Dunia kedua, perusahaan ini biasanya membangun kawasan industri di sekitar wilayah London. 
Namun, setelah Perang Dunia Kedua mereka mulai membangun dan mengembangkan kawasan industri di luar London, namun dekat dengan jalan tol yang dibangun oleh Pemerintah. Alasan dari pemilihan lokasi tersebut adalah agar produk dari kawasan industri tersebut mampu untuk mencukupi kebutuhan beberapa kota lain selain kota tempat kawasan industri tersebut berada (Bale, 1977).

\section{Pengembangan Kawasan Industri Oleh Pemerintah Daerah}

Selesainya Perang Dunia Kedua menjadikan Pemerintah daerah sebagai pelaku yang juga ikut membangun dan mengembangkan kawasan industri, bukan hanya sebagai fasilitator bagi perusahaan pengembang swasta. Menurut Bale (1977), tujuan utama Pemerintah daerah terlibat adalah untuk menciptakan lapangan pekerjaan baru di daerahnya. Namun, mendorong perusahaan-perusahaan baru, menyediakan properti dengan harga yang terjangkau, dan memberdayakan kembali lahan yang sudah tidak digunakan juga menjadi alasan Pemerintah daerah.

The Industrial Development Act (1966) yang diterbitkan oleh Pemerintah Inggris menyebutkan jika Pemerintah daerah serius untuk mengembangkan kawasan industri di daerahnya, Pemerintah pusat akan memberikan bantuan maksimum sebanyak 85 persen untuk setiap biaya yang dikeluarkan meremajakan kembali lahan yang terbengkalai menjadi kawasan industri, termasuk jika Pemerintah daerah tersebut akan melakukan reklamasi. Meskipun Pemerintah pusat Inggris sudah menunjukkan keseriusannya dalam membangun kawasan industri baru, banyak Pemerintah daerah yang hanya terhanyut dengan euforia tersebut dan hanya mampu mengembangkan kawasan industri yang hanya memiliki nama saja namun tidak mampu beroperasi (Bale, 1977).

\section{Pengembangan Kawasan Industri Oleh Pemerintah Pusat}

Bale (1977) menyebutkan jika kawasan industri yang oleh Pemerintah pusat Inggris memiliki kriteria: kebutuhan tenaga kerja di daerah tersebut, menarik atau tidaknya suatu daerah bagi perusahaan manufaktur, komunikasi yang baik, serta ketersediaan lahan untuk kawasan industri. Pada dasarnya, pembangunan kawasan industri oleh Pemerintah pusat ini memiliki tujuan utama yang sama dengan tujuan Pemerintah daerah, yakni menciptakan lapangan pekerjaan bagi masyarakat. Hal tersebut menyebabkan Pemerintah pusat banyak membangun kawasan industri yang berada pada wilayah yang belum memiliki infrastruktur yang mencukupi, sehingga Pemerintah pusat Inggris juga harus membangun infrastruktur baru untuk kawasan industri yang sedang dikembangkannya.

\subsubsection{Pengembangan Kawasan Industri Berdasarkan Rencana Pemerintah: Korea Selatan}

Secara umum, Korea Selatan membangun kawasan industrinya secara pesat pada periode 1960 hingga 1990an. Pemerintah Korea Selatan merencanakan pembangunan kawasan industri berdasarkan tujuh rencana jangka menengah lima tahunan selama tahun 1962 hingga 1997 dan tiga rencana jangka panjang 10 tahunan selama tahun 1972 hingga 2001.

\section{Pengembangan Kawasan Industri Tahun 1960an}

Pada awalnya, di Korea Selatan perusahaan-perusahaan manufaktur dibangun tersebar berdasarkan keinginan perusahaan tersebut. Kemudian sejak tahun 1960, Pemerintah Korea Selatan mulai menerbitkan rencana pembangunan infrastruktur fisik untuk lima tahun pertama dan mengembangkan beberapa kawasan industri yang memiliki fungsi masing-masing seperti kawasan industri 
untuk produk yang berorientasi ekspor, kawasan industri khusus industri besar, dan kawasan industri khusus pembangunan pedesaan (Kim dan Gallent, 1997). Diharapkan dengan adanya kawasan industri tersebut, Korea Selatan. mampu menciptakan self-sustaining ekonomi melalui industri yang bersifat labor intensive, seperti kayu, sepatu, dan tekstil. Namun, dalam rencana tersebut Pemerintah Korea Selatan juga menjadikan industri petrokimia sebagai market leader dalam pengembangan sektor industrinya (Kim dan Gallent, 1997).

Selama merencanakan pengembangan kawasan industri dan sektor yang utama, Pemerintah Korea Selatan juga melakukan investasi di bidang pembangunan infrastruktur, seperti jalan dan pelabuhan, untuk mendukung rencana tersebut. Selain itu, dalam pengembangan kawasan industri yang sudah ditetapkan, Pemerintah Korea Selatan menjamin kebutuhan dasar kawasan industri, seperti akses jalan, listrik, dan air baku, tersebut dibangun dan dipenuhi oleh Pemerintah. Bukti keterlibatan Pemerintah lainnya adalah dengan menjual lahan di kawasan industri dengan harga yang lebih murah untuk menarik minat investor, baik asing maupun lokal (Kim dan Gallent, 1997).

\section{Pengembangan Kawasan Industri Tahun 1970-an}

Pada periode ini, Pemerintah Korea Selatan mulai merubah fokus industri mereka dari light industries menjadi heavy industries yang bersifat capital intensive. Namun, semenjak tahun 1960an, beberapa kawasan industri yang bersifat export oriented sudah mulai menekankan produk logam dan permesinan sebagai syarat untuk free exchange technology dengan perusahaan asing di kawasan tersebut. Dengan beralihnya fokus pengembangan industri tersebut, industri besi dan baja serta petrokimia menjadi sektor industri penarik investasi terbesar -80 persen investasi industri di Korea Selatan ditujukan untuk mengembangkan kedua sektor tersebut (Kim dan Gallent, 1997).

Selain itu industri besi dan baja dan petrokimia, industri elektronik dan permesinan juga berkembang pesat pada periode ini. Dengan adanya industri besi dan baja, maka industri permesinan di Korea Selatan juga berkembang. Sedangkan industri elektronik di Korea Selatan sangat berfokus kepada industri elektronik yang mengandung teknologi baru yang sangat canggih, seperti pembuatan Chip komputer. Karena kebutuhan untuk mesin bagi industri elektronik ini juga sangat tinggi dan harus canggih, maka industri permesinan juga mengalami perkembangan yang pesat - ditambah dengan berkembangnya industri besi dan baja di Korea Selatan.

Selain mengubah sektor industri prioritas mereka, Pemerintah Korea Selatan juga melakukan relokasi beberapa kawasan industri yang sebelumnya berada di pusat kota, termasuk di Seoul, menuju wilayah pinggir kota. Hal tersebut ditujukan untuk mampu menampung industri kecil menengah yang sedang berkembang di luar kota besar. Selain itu, pemindahan tersebut juga dilakukan untuk menjauhkan kawasan industri yang berpolusi tinggi dari kawasan pemukiman yang saat itu berada di tengah kota (Kim dan Gallent, 1997).

\section{Pengembangan Kawasan Industri Tahun 1980-an}

Pada periode ini sektor industri yang menjadi prioritas adalah industri yang memiliki kandungan teknologi yang tinggi, seperti semikonduktor, komputer, mobil, kapal terbang, bioteknologi, dan material baru. Hal tersebut dapat dilihat dari komposisi industri yang memiliki teknologi tinggi mencapai 57,3 persen di wilayah ibukota (Kim dan Gallent, 1997). 
Skala industri yang berada di kawasan industri yang berada tengah kota besar juga berubah menjadi industri yang berskala kecil dan menengah, sedangkan kawasan industri untuk industri besar dan sedang dikembangkan di daerah pesisir barat Korea Selatan - selama ini kawasan industri berpusat di pesisir timur Korea Selatan. Pengembangan tersebut ditujukan untuk mengurangi ketimpangan yang terjadi di Korea Selatan akibat pembangunan industri di wilayah pesisir timur

\subsection{Identifikasi Faktor-faktor Penting Dalam Pembangunan Industri Berbasis Kawasan Industri}

Sebagai rangkuman dari bagian ini, dapat diidentifikasi beberapa faktor penting dalam pembangunan industri berbasis kawasan dengan mengombinasikan studi literatur terkait kebijakan industri dan best practice pengembangan KI yakni antara lain:

- Peran Pemerintah dalam mengeluarkan kebijakan industri sangat berpengaruh pada pertumbuhan dan perkembangan industri di suatu negara dengan berfokus pada penyelesaian hambatan-hambatan yang ada dengan berkolaborasi dengan pelaku usaha dibandingkan fokus kepada outcome target tertentu yang ditentukan Pemerintah sendiri

- Dalam praktiknya, penerapan kebijakan industri baik Pemerintah sebagai mediator dan fasilitator pelaku usaha (contoh: Korea) maupun Pemerintah sebagai penentu tahapan-tahapan pembangunan industri dan sektor-sektor industri prioritas (contoh: Taiwan), menitikberatkan pada koordinasi dan kolaborasi dengan pelaku usaha di sektor industri

- Keberhasilan pembangunan sektor industri biasanya melewati tahapantahapan fundamental yang sulit untuk di-shortcut walaupun bisa diakselerasi. Tahapan-tahapan tersebut biasanya dimulai dari industri yang bersifat labor intensive, kemudian berlanjut ke industri basis dan heavy industries yang lebih bersifat capital intensive (industri logam, dan permesinan), kemudian baru dilanjutkan dengan industri berteknologi tinggi, serta services industry. Sehingga prioritas dari fasilitasi Pemerintah berupa regulasi, perbaikan iklim dan investasi, insentif fiskal dan non fiskal, dan lain-lain, lebih diarahkan kepada industri-industri yang menjadi prioritas pada tahapan tertentu

- Kawasan industri harus menarik minat investor dari sisi bisnis dan economic of scale. Ketersediaan infrastruktur pendukung sebagai prasyarat lainnya harus dapat dipenuhi oleh Pemerintah ataupun kolaborasi antara Pemerintah (Pusat dan daerah) dengan swasta. Pola keterkaitan intra dan inter-kawasan dapat pula ditetapkan dalam kebijakan industri untuk memperoleh nilai tambah setinggi-tingginya di dalam negeri

\section{Overview Pembangunan Industri Berbasis Kawasan Industri di Indonesia} 3.1. Kondisi Saat Ini

Jumlah industri besar berdasarkan data terakhir statistik industri besar dan sedang (BPS, 2015) adalah 7.827 sedangkan industri menengah/sedang berjumlah 18.495 dengan nilai tambah total masing-masing Rp.1.667 triliun untuk industri besar dan Rp. 226 triliun untuk industri sedang. Sementara itu industri kecil dan mikro berjumlah lebih dari 8.7 juta dengan nilai tambah total Rp 220 triliun. 


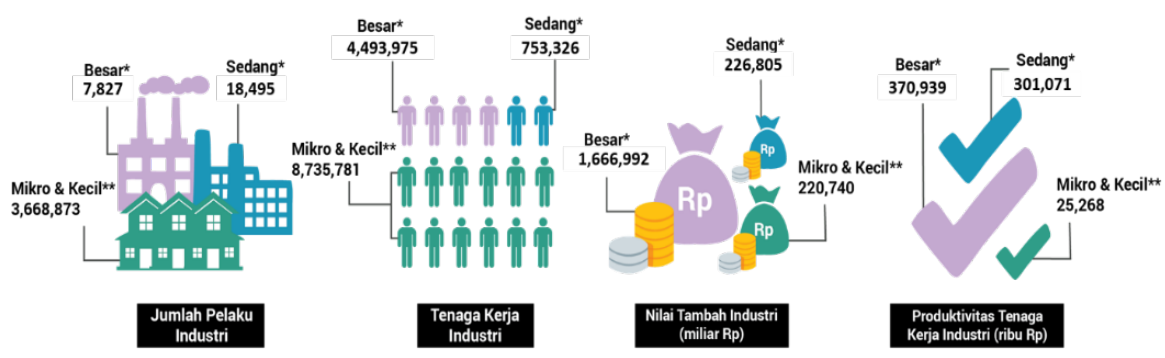

Gambar 2. Jumlah Industri Besar

Sumber: BPS, diolah oleh Direktorat Industri, Pariwisata dan Ekonomi Kreatif Badan Perencanaan Pembangunan Nasional, 2017

Apabila dilihat dari persebarannya, sebanyak $81.5 \%$ industri besar dan menengah berada di Pulau Jawa. Demikian pula halnya dengan kawasan industri, saat ini di luar KIP dan kawasan industri baru milik swasta yang pembangunannya on-going, jumlah kawasan industri di Indonesia adalah 74 kawasan dan sebagian besar di antaranya ada di pulau Jawa (Kementerian Perindustrian, 2013). Karena itu inisiasi pembangunan KIP di luar Jawa tentunya diharapkan dapat memperbaiki ketimpangan persebaran industri yang terjadi saat ini.

\begin{tabular}{ccccccc}
\hline TAHUN 2015 & JAWA & SUMATERA & KALIMANTAN & SULAWESI & $\begin{array}{c}\text { BALI-NUSA } \\
\text { TENGGARA }\end{array}$ & $\begin{array}{c}\text { MALUKU- } \\
\text { PAPUA }\end{array}$ \\
\hline $\begin{array}{c}\text { Jumlah Unit } \\
\begin{array}{l}\text { Usaha Besar } \\
\text { dan Sedang }\end{array}\end{array}$ & 21,460 & 2,785 & 591 & 681 & 674 & 131 \\
$\begin{array}{c}\text { Persebaran } \\
(\%)\end{array}$ & 81,5 & 10,6 & 2,2 & 2,6 & 2,6 & 0,5 \\
\hline
\end{tabular}

Sumber data: BPS, diolah oleh Direktorat Industri, Pariwisata dan Ekonomi Kreatif Badan Perencanaan Pembangunan Nasional, 2017)

Kemudian pembangunan pabrik dan fasilitas industri diharapkan ada dalam satu kawasan sebagaimana contoh-contoh dalam best practice di dunia sesuai pembahasan dalam literature review pada bagian sebelumnya. Walaupun data resminya belum berhasil diperoleh, namun secara observasi di beberapa daerah di Indonesia kita dapat melihat lokasi pabrik dan fasilitas pendukung masih tersebar di luar kawasan industri. Untuk itu Kementerian Perindustrian berencana menertibkan industri yang berlokasi di luar kawasan khususnya yang berada di dekat perumahan dan permukiman penduduk. Kebijakan ini diambil demi menjalankan amanat Undang-Undang (UU) Nomor 3 tahun 2014 tentang Perindustrian. Selain itu tentunya persebaran industri di luar kawasan yang bersifat 'scattered tentunya akan menyulitkan Pemerintah dalam memfasilitasi kebutuhan infrastruktur dan penentuan kebijakan pengembangan sektor industri (kemenperin.go.id, 2014).

\subsection{Pola Kebijakan Pembangunan Industri Saat Ini}

Apabila kita melihat perencanaan sektor industri dalam dokumen-dokumen perencanaan (RPJMN, Rencana Kerja Pemerintah/RKP, Rencana Strategis/Renstra Kementerian dan Lembaga/KL, dll), permasalahan utama yang 
sering terlihat adalah kurang jelasnya keterkaitan antara kebijakan dan target dengan program dan kegiatan yang dilakukan oleh Pemerintah. Dengan kata lain, untuk sektor industri kontribusi dari tiap program dan kegiatan KL terkait terhadap target pertumbuhan dan implementasi kebijakan di bidang industri yang telah ditetapkan masih agak kurang terukur. Idealnya dalam penentuan target perlu diidentifikasi kondisi baseline tanpa intervensi program dan kegiatan Pemerintah, untuk kemudian dihitung 'gap' antara baseline tersebut dengan target yang ingin dicapai yang diharapkan dapat dipenuhi melalui program dan kegiatan Pemerintah. Contohnya pembangunan KIP yang menjadi flagship dari kebijakan Industri (dengan pertimbangan kegiatan lainnya di luar pembangunan KIP masih mirip dengan kegiatan-kegiatan tahun sebelumnya) merupakan proyek jangka menengah-panjang yang tidak langsung terlihat hasilnya dalam jangka pendek sehingga kurang sesuai dengan penetapan target pertumbuhan industri tahunan yang mencapai 5-6 \% (RPJMN 2010-2014). Untuk itu perlu juga dikembangkan perhitungan akurat tentang realisasi dampak dari kebijakan apakah dirasakan dalam jangka pendek, menengah, atau panjang sehingga dapat disesuaikan dalam penetapan target.

Permasalahan lainnya adalah kolaborasi yang masih minim dengan pelaku usaha. Sesuai analisis dalam literatur, jelas digambarkan bahwa kebijakan industri di negara-negara yang industrinya maju selalu melibatkan pelaku usaha secara aktif karena yang nantinya menjalankan operasi industri adalah para pelaku usaha. Karena itu penentuan target, sektor prioritas, dan kebijakan lainnya tidak sematamata merupakan inisiatif dan pandangan normatif dari Pemerintah ataupun tenaga ahli yang ditunjuk saja.

Kemudian pola kebijakan industri juga masih bersifat sporadis dan kurang mendukung struktur pembangunan industri yang kokoh. Artinya prioritas sektor industri mana yang akan dikembangkan masih belum berdasarkan tahapan-tahapan fundamental sesuai pengalaman negara-negara industri pada umumnya, yakni dimulai dengan memperkuat industri padat karya kemudian industri basis (industri kimia, logam, permesinan, dll) dan seterusnya hingga industri berteknologi tinggi. Bahkan prioritizing industri sendiri saat ini masih belum jelas karena semua industri diprioritaskan secara paralel. Kalaupun memang ada kebijakan 'breakthrough' untuk melakukan shortcut terhadap tahapan-tahapan fundamental tersebut perlu didefinisikan secara jelas arah kebijakannya dan komitmen pelaksanaannya.

Isu lainnya adalah koordinasi lintas sektoral karena tentunya berbicara pembangunan industri tidak hanya tanggung jawab Kementerian Perindustrian. Namun pada kenyataannya, koordinasi lintas KL masih menjadi isu baik dalam bentuk regulasi maupun kebijakan dan implementasinya. Bahkan untuk internal antar unit di Kementerian Perindustrian saja koordinasinya masih perlu diperbaiki. Belum lagi apabila kita kaitkan dengan perencanaan regional di mana saat ini belum ada bridging yang jelas untuk perencanaan lintas wilayah dan lintas sektoral baik dalam bentuk regulasi dan kebijakan tertulis maupun dalam hal praktik dan implementasinya di lapangan.

\subsection{Analisis Pendekatan Fundamental Pertumbuhan Industri}

Apabila kita menarik analisis fundamental paling sederhana terkait pertumbuhan industri, dapat diidentifikasi sumber utama dari pertumbuhan industri adalah investasi baru (ekspansi kapasitas produksi atau pembangunan pabrik baru) dan peningkatan utilitas dari kapasitas saat ini. Kedua hal tersebut tentu saja didasarkan pada perkembangan market (demand) dan keputusan pelaku usaha untuk berinvestasi (supply). Apabila kita menitikberatkan pada ekspansi usaha dan investasi 
baru, tentunya dari sisi pelaku usaha harus jelas ada potensi bisnis (profit) yang menarik dengan keputusannya berinvestasi, dimana profit secara fundamental diukur dari selisih cost dikurangi revenue atau dari tingginya value added yang diperoleh. Dengan kata lain, profit dapat diperoleh melalui penurunan cost, peningkatan revenue dan peningkatan value added.

Apabila kita petakan untuk sektor industri, gambaran umum dari skema costvalue added-revenue dapat dilihat pada skema berikut ini:

\begin{tabular}{|c|c|c|}
\hline $\begin{array}{l}\quad \text { Reduce Cost } \\
\text { CAPEX: Lahan, bangunan, equipment + } \\
\text { Biaya Overhead investasi (tergantung } \\
\text { pada easiness of doing business) } \\
\text { OPEX: } \\
\text { - Bahan baku } \\
\text { - Energi } \\
\text { - Logistik/supply chain } \\
\text { Others: } \\
\text { - Biaya Tenaga Kerja } \\
\text { - Overhead, dst }\end{array}$ & $\begin{array}{l}\text { Increase Value added } \\
\text { - Penguasaan Teknologi } \\
\text { - Kualitas SDM } \\
\text { - } \text { dst }\end{array}$ & $\begin{aligned} & \text { Increase revenue } \\
& \text { - Perluasan Akses Pasar } \\
& \text { - Peningkatan Demand } \\
& \text { - } \text { dst }\end{aligned}$ \\
\hline
\end{tabular}

Skema di atas merupakan analisis dasar bagaimana pelaku usaha meutuskan untuk berinvestasi. Dari sisi cost tentunya ada yang bersifat capital expenditure (capex) yang pada umumnya didominasi oleh biaya lahan, bangunan, mesin dan overhead yang sangat tergantung iklim usaha dan easiness to start/doing business. Kemudian untuk operational expenses (opex), berdasarkan data statistik industri besar-sedang (BPS, 2015), secara umum komponen cost terbesar adalah bahan baku, energi, logistik dan biaya tenaga kerja. Dari sisi value added tentunya inovasi, penguasaan teknologi produksi dan keahlian SDM adalah poin utama. Sedangkan dari sisi revenue, peningkatan demand dan perluasan akses pasar menjadi faktor utama dalam peningkatan penjualan produk industri. Pada akhirnya, pelaku usaha akan memutuskan untuk berinvestasi apabila minimal salah satu di antara reduce cost, increase value added dan increase revenue apabila dijumlahkan mampu memberikan profit maksimum dibandingkan pilihan pada alternatif investasi lainnya.

Kondisi saat ini menunjukkan bahwa dari sisi cost, daya saing Indonesia masih cukup tertinggal yang ditunjukkan dengan tingginya biaya energi dan logistik dibandingkan negara pesaing (BPS, 2015). Kemudian kurang terkelolanya bahan baku terutama raw material sehingga standar quality-cost-delivery-nya (QCD) tidak selalu memenuhi standar ekspektasi pelaku industri. Melalui observasi dan diskusi dengan instansi terkait termasuk pelaku usaha, ditemukan bahwa sebagian besar raw material dan bahan baku belum terintegrasi langsung dengan industri khususnya bahan baku yang berasal dari sektor primer (pertanian, perkebunan, dan pertambangan). Demikian pula halnya dengan inovasi, penguasaan teknologi industri dan kualitas SDM kita yang juga belum dapat menjadi andalan. Satusatunya keunggulan kita adalah akses pasar yang sangat luas yang dibuktikan dengan konsentrasi industri yang banyak dibangun dekat dengan pasar yang besar (di kota-kota besar di pulau Jawa dan Sumatera) khususnya industri consumer product. Analisis lebih lanjut terkait pendekatan fundamental untuk cost reduction (analisis cost 
structure di sektor industri), increase value added (terutama terkait inovasi teknologi dan kualitas SDM), serta increase revenue (new market atau meningkatkan share dari existing market) sangat menarik untuk diperdalam. Namun karena keterbatasan periode waktu dan resources pendalaman tersebut sulit untuk dilakukan secara lebih komprehensif dan detail, sehingga sangat direkomendasikan untuk dilanjutkan dalam studi-studi berikutnya.

Kemudian apabila kita kaitkan dengan pembangunan kawasan industri, agar suatu kawasan menarik minat investor tentunya prinsip dasar reduce cost-increasevalue added-increase revenue tadi juga harus dapat memberikan profit maksimum bagi calon investor di KI tersebut. Secara umum ada 3 investor di KI yakni investor pemilik dan pengelola kawasan, investor penyedia utilitas, dan investor industri sebagai aktor utama. Artinya kawasan industri yang ditunjuk harus terbukti melalui perhitungan yang akurat memberikan keuntungan bagi ketiga jenis investor tadi. Salah satu breakthrough yang dapat dilakukan adalah sejak awal melibatkan pelaku usaha dan calon investor untuk menilai kelayakan suatu wilayah untuk menjadi kawasan industri termasuk untuk mengidentifikasi problem dan gap yang membutuhkan dukungan Pemerintah agar dapat direalisasikan.

Dalam hal pemerataan industri di luar Jawa, tentunya akan sulit menemukan kawasan industri yang murni feasible secara bisnis. Untuk itu peran Pemerintah dalam mengisi gap yang ada dalam analisis bisnis agar investasi di KI menjadi feasible sangat diperlukan, khususnya penyediaan infrastruktur dan fasilitas pendukung hingga akhirnya kawasan tersebut menarik bagi investor. Namun di sini juga harus dipertimbangkan kebutuhan anggaran Pemerintah dibandingkan dampak dari dibangunnya kawasan industri tersebut. Dengan kata lain harus layak secara cost and benefit analysis (CBA) yang tentunya terkait dengan efisiensi penggunaan anggaran, serta tetap melibatkan pelaku usaha dalam CBA tersebut untuk meningkatkan akurasi perhitungan secara bisnis.

Saat ini praktis dari 14 lokasi KIP di dalam perencanaan hanya 3 KIP yang sudah mulai beroperasi dalam magnitude yang cukup memadai yakni KI Sei Mangke, KI Morowali, dan KI Konawe. Untuk KI Sei Mangke, operasionalisasinya sendiri masih bermasalah dengan harga gas yang menjadi salah satu bahan baku utama industri oleochemical yang dijalankan oleh Unilever sebagai anchor industry. Sementara KI Morowali dan KI Konawe dapat beroperasi karena dikembangkan oleh investor yang langsung berinvestasi secara total baik sebagai anchor industry, pengelola dan penyedia utilitas termasuk layanan logistik.

Apabila kita melakukan review terhadap feasibility study dan business plan dari 14. KIP yang ada, terlihat bahwa akurasi dari perhitungan yang dilakukan masih sangat kurang. Apalagi keterlibatan pelaku usaha dalam penyusunan FS juga sangat minim. Kebanyakan KIP juga langsung merencanakan lahan yang sangat besar hingga ribuan hektar dalam FS, yang tentunya memberatkan investor pengelola untuk berinvestasi. Kemudian value proposition (terkait keunggulan dalam cost reduction, nilai tambah dan akses pasar) juga belum terdefinisi atau disimulasikan dengan akurat. Akhirnya FS dan rencana yang dibuat tidak berhasil menarik minat investor untuk beraktivitas di kawasan tersebut.

Sebagian besar KIP juga telah memiliki master plan tanpa didukung kepemilikan tanah yang memadai. Hal ini agak membingungkan karena tentunya sangat sulit merealisasikan masterplan di lahan yang dimiliki orang lain yang belum dikuasai tanpa kejelasan kapan akan dapat dibebaskan ke depannya. Selain itu juga 
persiapannya terkesan terburu-buru dan sangat minim melibatkan pelaku usaha serta pengembang yang berpengalaman dalam pembangunan KI. Hal ini bisa saja berindikasi adanya kemungkinan bahwa FS dan masterplan yang disusun hanya dianggap sebagai kelengkapan administrasi atau hanya berupa justifikasi terhadap pemilihan lokasi tertentu sebagai KIP.

\subsection{Identifikasi Poin-Poin Permasalahan Berdasarkan Kondisi Saat Ini dan Hasil Analisis}

Berdasarkan pembahasan sebelumnya, dapat diidentifikasi dan dirangkum poin-poin permasalahan antara lain:

- Pola kebijakan industri masih belum jelas dan masih sporadis. Penentuan target kurang berhubungan dengan program dan kegiatan Pemerintah terkait sektor industri. Prioritas industri juga masih meliputi seluruh sektor secara paralel tanpa tahapan yang jelas sesuai pengalaman negara-negara yang maju industrinya, ataupun apabila ingin melakukan 'shortcut' dari tahapan-tahapan tersebut belum terlihat jelas breakthrough yang dilakukan. Hal ini secara langsung terkait dengan pembangunan dan pengembangan KI termasuk hubungan dan interaksi antar KI yang produk/komoditinya saling terkait.

- Kurangnya kolaborasi dan koordinasi dengan pelaku usaha dalam perencanaan dan implementasi kebijakan industri

- Industri masih banyak yang beroperasi 'scattered di luar KI dan roadmap untuk penertiban dan realokasi bertahap masih belum ditetapkan dengan komitmen untuk dilaksanakan

- Perencanaan dan FS dari sebagian besar KIP kurang menarik bagi investor. FS dan masterplan kurang akurat dan cenderung hanya menjadi justifikasi agar pembangunan dapat berjalan. Kompetensi penilai proyek khususnya di lingkungan unit kerja Pemerintah terkait juga dipertanyakan pada periode penyiapan FS dan masterplan tersebut

- Tahapan pembangunan KIP dalam implementasi juga masih belum tergambar jelas dan kadang-kadang urutan pembangunan dan pengembangannya terlihat kurang tepat seperti membangun pengolah limbah dan asrama pegawai terlebih dahulu padahal belum ada tenant industri yang beroperasi, dll.

- Belum jelas tindak lanjut yang akan dilakukan dengan existing KIP yang saat ini progresnya terhenti atau sangat lambat kemajuannya.

\section{Rekomendasi Kebijakan Terkait Pembangunan Industri Berbasis Aglomerasi (Kawasan) Industri}

Rekomendasi kebijakan dianalisis secara ringkas berdasarkan identifikasi dan analisis permasalahan-permasalahan yang dilakukan pada bagian sebelumnya yang terdiri dari rekomendasi terkait pola kebijakan pembangunan industri; rekomendasi terkait tahapan-tahapan pembangunan KI secara umum; rekomendasi terkait langkah-langkah yang perlu diambil untuk existing KI yang sudah ditetapkan namun belum memiliki progress yang baik; rekomendasi terkait mainstream kebijakan yang diperlukan dalam membangun industri berbasis aglomerasi atau kawasan industri; serta terakhir akan dijelaskan lebih lanjut rekomendasi terkait kebutuhan studi-studi berikutnya. 


\subsection{Perbaikan Pola Kebijakan Pembangunan Industri}

Agar tidak bersifat business as usual dan meneruskan pola kebijakan saat ini yang kurang efektif, beberapa perbaikan pola kebijakan industri yang dapat direkomendasikan antara lain:

- Penyusunan target harus memperhitungkan 'gap' dari baseline berdasarkan kondisi saat ini tanpa intervensi Pemerintah, untuk kemudian gap tersebut nantinya harus diisi dengan program dan kegiatan Pemerintah sehingga terlihat jelas hubungan antara program dan kegiatan dengan kontribusinya terhadap pencapaian target

- Perlu disusun roadmap tahapan pembangunan industri dengan prioritas yang jelas dan tidak terlalu banyak sesuai tahapan yang ditentukan, memprioritaskan semua subsektor industri secara paralel sama saja dengan tidak memprioritaskan apapun.

- Industri prioritas tentunya dapat difasilitasi agar value propositionnya (cost yang lebih rendah, peningkatan revenue melalui akses pasar yang lebih luas, penguatan inovasi dan penguasaan teknologi, dll) dapat berkembang

- Apabila ingin melakukan 'shortcut' yang berbeda dari tahapan pengembangan industri sesuai best practice dari pengalaman negara-negara yang maju industrinya, perlu ditentukan breakthrough apa yang dapat dilakukan berikut strategi, tahapan-tahapan implementasi dan komitmen pelaksanaannya

- Kebijakan industri jangka panjang (roadmap, prioritas industri, dan tahapantahapan) sesuai poin-poin sebelumnya apabila perlu dapat ditetapkan dalam bentuk Undang-Undang dengan konten yang tajam (tidak normatif) agar pelaksanaannya tetap terkawal walaupun ada pergantian Pemerintahan dan kepemimpinan

- Kebijakan industri harus ditetapkan secara lintas sektor dan lintas region

- Penyusunan dan implementasi kebijakan sedapat mungkin berkolaborasi dengan pelaku usaha terkait, tidak hanya dari sudut pandang Pemerintah saja termasuk pada proses perencanaan dan penyusunan target

\subsection{Rekomendasi Tahapan-tahapan Pembangunan KI}

Berdasarkan permasalahan-permasalahan yang telah dianalisis sebelumnya, tahapan-tahapan yang secara umum diperlukan dalam pembangunan dan pengembangan KI antara lain:

- Penetapan lokasi-lokasi yang berpotensi dan jelas value proposition-nya (reduce cost, increase value added, increase revenue)

- Penyusunan Feasibility Study yang bukan merupakan justifikasi terhadap lokasi yang ditunjuk dan disepakati sebelumnya (tidak hanya melalui pendekatan politik ataupun keputusan pimpinan). Namun harus berupa perhitungan dan analisis yang detail, akurat, kredibel, dan sebisa mungkin melibatkan pelaku usaha dan institusi berpengalaman dalam FS KI, termasuk perusahaan pengelola KI yang telah established. Hasil akhir dari FS tentunya tidak harus selalu feasible (FS bukan hanya persyaratan administrasi). Kemungkinan hasil FS antara lain murni feasible secara bisnis; feasible dengan gap yang harus dipenuhi Pemerintah (tidak feasible secara bisnis tapi feasible secara cost and benefit); atau tidak feasible sama sekali

- Untuk KI yang sudah feasible (murni atau dengan gap) dan diputuskan untuk dikembangkan lebih lanjut, perlu dilakukan analisis market atau market study 
untuk menentukan target investornya (pengelola, penyedia utilitas, dan industri) dengan mempertimbangkan persaingan dengan daerah/negara lain yang juga memiliki kawasan potensial untuk menjadi KI. Dengan kata lain perlu dipastikan bahwa berinvestasi di KI tersebut tidak hanya feasible saja, tetapi lebih menguntungkan atau lebih feasible dibandingkan lokasi lainnya yang dapat menjadi alternatif termasuk di luar negeri

- Setelah itu dapat dipasarkan lokasi-lokasi yang feasible (secara bisnis/finansial, ataupun secara cost and benefit analysis dengan dukungan Pemerintah) ke pihak swasta atau BUMN (sebagai investor pengelola, penyedia utilitas, atau anchor industry)

- Setelah ada investor pengelola, dapat dilakukan penyiapan masterplan, engineering design, dan pola pengembangan khususnya pada lahan yang telah dibebaskan, yang dilakukan secara profesional oleh pengelola yang tentunya dapat berkolaborasi dengan investor lainnya (penyedia utilitas dan calon tenant terutama anchor industry)

- Kemudian pengembangan dan penyediaan infrastruktur kawasan yang dapat dikerjakan oleh pengelola dengan fasilitasi dan dukungan Pemerintah khususnya untuk infrastruktur pendukung di luar kawasan

Khusus untuk KI di luar Jawa dengan gap infrastruktur yang besar, model fasilitasi Pemerintah dapat berupa Penyertaan Modal Negara (PMN) ke pengelola (BUMN/BUMD) atau ke BUMN terkait lainnya seperti PLN untuk infrastruktur listrik, Pelindo untuk Pelabuhan, dll, untuk meminimalisir transaction cost apabila dibandingkan pengalokasian anggaran lewat $\mathrm{K} / \mathrm{L}$ tertentu. Alternatif lewat skema kerjasama Pemerintah dengan Badan Usaha (Perusahaan) juga dapat diimplementasikan apabila memungkinkan.

\subsection{Langkah-Langkah Untuk Existing KIP yang Telah Dibangun}

Karena fasilitasi untuk 14 KIP telah dilakukan dan anggaran yang cukup besar juga sudah dialokasikan, agar KIP yang progresnya masih lambat tidak berhenti di tengah jalan, beberapa hal yang dapat dilakukan secara umum antara lain:

- Perlu dilakukan reassesment lagi terhadap kelayakan dari KIP yang belum berkembang (FS, cost-benefit analysis, dan market study yang akurat dan kredibel) dengan melibatkan pelaku usaha dan calon investor. Cost factor terkait keterjangkauan lokasi di luar pulau Jawa dan biaya logistik pembangunan dapat menjadi perhatian.

- Apabila ternyata belum feasible untuk menjadi kawasan industri besar, KIP yang telah ditetapkan bisa juga dimulai dengan kawasan Industri Kecil Menengah (IKM) terlebih dahulu

- Investment cost juga menjadi pertimbangan karena berdasarkan informasi dari Himpunan Kawasan Industri (HKI), biaya clean and clear tanah saja rata-rata dapat mencapai 30-35 USD per m2 (di luar harga perolehan). Untuk itu pembangunan KIP bisa dilakukan secara bertahap mulai dari luasan lahan kecil dulu (20-50 ha) terlebih dahulu

- Untuk KI dengan proses utama berupa industri smelter logam, cost and benefit harus benar-benar dipertimbangkan (tidak hanya dari sisi bisnis saja). Bargaining position nasional harus diutamakan terkait nilai tambah, SDM, teknologi, dan dampak terhadap lingkungan/sosial. Harus diingat pula bahwa nota kesepahaman (Memorandum of Understanding/MoU) bukan merupakan agreement 
sehingga perlu dilakukan perjanjian kerjasama yang jelas terkait hilirisasi, tenaga kerja, dan isu penting lainnya. Selanjutnya industri hilir ataupun intermediate sebenarnya secara bisnis tidak harus berlokasi di dekat smelter (cost dan risiko malah lebih tinggi). Karena itu perjanjian kerjasama bisnis dengan investor industri hilir dari hasil smelter harus benar-benar disusun dengan prinsip kehati-hatian

- Perlu standarisasi investor yang akan masuk (teknologi yang dibawa, permodalan dan kesehatan perusahaan, dll)

\subsection{Mainstream Kebijakan untuk Pembangunan Industri Berbasis Kawasan}

Berdasarkan analisis dan pembahasan sebelumnya, beberapa hipotesis terkait mainstream kebijakan terkait pembangunan industri berbasis aglomerasi (Kawasan) industri antara lain:

- Pembangunan industri harus berada di dalam KI sesuai amanat Undang-Undang (UU) Nomor 3 tahun 2014 tentang Perindustrian. Artinya untuk pembangunan industri baru, sejak awal harus diarahkan di dalam KI. Untuk industri yang saat ini masih berada di luar KI harus dibuat roadmap agar secara bertahap pindah ke dalam KI.

- Pelaku usaha adalah aktor penting yang tidak hanya bersifat pasif namun diharapkan dapat aktif berkolaborasi dengan Pemerintah khususnya untuk pembangunan dan pengembangan industri berbasis aglomerasi (Kawasan) industri, tentunya sesuai dengan peraturan yang berlaku

- Keterkaitan intra dan inter kawasan industri harus didesain sedemikian sehingga nilai tambah dalam value chain produksi mampu dioptimalkan di dalam negeri. Keterkaitan input-output produksi intra dan inter kawasan perlu menjadi perhatian, kemudian supply chain dan value chain dari produk industri dalam negeri harus dapat direkayasa melalui kebijakan untuk memaksimalkan nilai tambah nasional termasuk dukungan untuk terlibat dalam global supply chain dan global value chain

- Selain penentuan sektor industri prioritas, penentuan KI prioritas secara operasional juga diperlukan yang tentunya sejalan dengan pengembangan sektor industri prioritas yang telah ditetapkan

\subsection{Rekomendasi Untuk Studi Berikutnya}

Studi ini sejauh ini masih memberikan gambaran umum permasalahan dan hipotesis rekomendasi kebijakan berdasarkan analisis dasar menggunakan logika fundamental dalam hal sumber pertumbuhan industri yang berdasarkan keputusan pelaku usaha untuk berinvestasi, dengan dukungan beberapa referensi terutama yang terkait dengan best practices kebijakan industri dan pengembangan KI di beberapa negara yang relevan dengan situasi dan kondisi di Indonesia. Karena keterbatasan periode waktu dan sumber daya, tentunya ada beberapa hal penting yang belum tercakup dalam studi ini. Beberapa kebutuhan pendalaman terhadap analisis yang dilakukan dalam paper ini untuk dapat diteruskan pada studi-studi berikutnya antara lain:

- Analisis lebih lanjut terkait pendekatan fundamental untuk cost reduction (analisis cost structure di sektor industri), increase value added (terutama terkait inovasi teknologi dan kualitas SDM), serta increase revenue (new market atau meningkatkan share dari existing market) di berbagai wilayah di Indonesia yang 
berpotensi untuk pembangunan dan pengembangan KI, yang dapat dibuat dalam database yag akurat dan dinamis mengikuti perkembangan

- Analisis lebih dalam terkait strategi tahapan-tahapan pembangunan industri yang paling sesuai untuk dikembangkan di Indonesia sesuai potensi yang dimiliki (SDA, SDM, inovasi teknologi, dll) dan peluang yang ada pada saat ini dan di masa depan

- Analisis 'rekayasa value chain' dalam arti melakukan fasilitasi antar industri ataupun kawasan industri yang terkait satu sama lain untuk meningkatkan nilai tambah setinggi-tingginya di dalam negeri termasuk peluang untuk ikut ambil bagian dalam global supply chain dan global value chain. Analisis ini tentunya dapat terintegrasi dengan data dan informasi dalam 'database' KI sesuai penjelasan di poin sebelumnya

- Karena sifatnya masih hipotesis, diperlukan analisis dan studi lebih lanjut terkait rekomendasi mainstream pola kebijakan di atas termasuk kemungkinan identifikasi mainstream tambahan lainnya

Untuk kedalaman analisis ke depan, keterlibatan pelaku usaha serta stakeholder-stakeholder lintas sektor-lintas region terkait juga sangat dibutuhkan, yang masih sangat terbatas diimplentasikan dalam studi ini. Apalagi saat ini terdapat 34 Provinsi dan 542 Kabupaten/Kota yang masing-masing memiliki kebijakan khusus yang sangat berpengaruh pada kegiatan sektor industri. Pada akhirnya apabila kebutuhan-kebutuhan analisis dan studi di atas dapat terpenuhi, diharapkan akan diperoleh roadmap pembangunan industri berbasis aglomerasi (Kawasan) industri dan 'rekayasa value chain' yang tidak hanya dalam bentuk rekomendasi kebijakan normatif namun juga termasuk strategi implementasinya yang komprehensif, tepat sasaran, serta terutama dapat direalisasikan dalam langkah-langkah dan eksekusi yang nyata dengan komitmen dari seluruh stakeholder terkait.

\section{Daftar Pustaka}

Badan Pusat Statistik (2017), Produk Domestik Bruto Berdasarkan Lapangan Usaha, Jakarta, diolah oleh Direktorat Industri, Pariista, dan Ekonomi Kreatif, Bappenas

Badan Pusat Statistik (2017), Pertumbuhan Ekonomi Indonesia Triwulan III/2017, Jakarta, diolah oleh Direktorat Industri, Pariista, dan Ekonomi Kreatif, Bappenas

Badan Pusat Statistik (2015), Statistik Industri Besar Sedang, Jakarta, diolah oleh Direktorat Industri, Pariwisata, dan Ekonomi Kreatif, Bappenas

Badan Pusat Statistik (2015), Statistik Industri kecil dan Mikro, Jakarta, diolah oleh Direktorat Industri, Pariwisata, dan Ekonomi Kreatif, Bappenas

Bale, J., (1974). Towards a Definition of the Industrial Estate: A Note on a Neglected Aspect of Urban Geography. Geography, January, 59(1), pp. 31-34.

Bale, J., (1977). Industrial Estate Development and Location in Post-war Britain. Geography, April, 62(2), pp. 87-92.

Bureau of Social Affairs, United Nations, 1962. Physical Planning Considerations Relating to Industrial Estates, s.l.: Athens Center of Ekistics. 
Fong, C., (1980). Planning for Industrial Estate Development in A Developing Economy. Management Science, 26(10), pp. 1061-1067.

Kementerian Perencanaan Pembangunan Nasional, Republik Indonesia (2014). Rencana Pembangunan Jangka Menegah Nasional (RPJMN) 2015-2019.

Kementerian Perencanaan Pembangunan Nasional, Republik Indonesia (2015). Rencana Kerja Pemerintah (RKP) 2016.

Kementerian Perencanaan Pembangunan Nasional, Republik Indonesia (2016). Rencana Kerja Pemerintah (RKP) 2017.

Kementerian Perindustrian republic Indonesia (2014), Industri Wajib Berlokasi di Kawasan Industri, http://www.kemenperin.go.id/artikel/9252/IndustriWajib-Berlokasi-di-Kawasan-Industri, dikutip pada tanggal 24 November 2017

Kementerian Perindustrian Republik Indonesia (2014), Pabrik di Luar Kawasan Terancam Pidana, http://www.kemenperin.go.id/artikel/7649/Pabrik-diLuar-Kawasan-Terancam-Pidana, dikutip pada tanggal 24 November 2017

Kim, K. \& Gallent, N., (1997). Industrial Park Development and Planning in South Korea. Regional Studies, June, 31(4), pp. 424-430.

Lall, S., (2003). Reinventing Industrial Strategy: The Role of Government Policy in Building Industrial Competitiveness, s.l.: G24 Intergovernmental Group on Monetary Affairs and Development.

Rodrik, D., (1994). Getting Interventions Right: How South Korea and Taiwan Grew Rich, Cambridge: s.n.

Rodrik, D., (2004). Industrial Policy for The Twenty-First Century. S.L.:Unido.

Stiglitz, J. E., (1996). Some Lessons from The East Asian Miracle. The World Bank Research Observer, Agustus, 11(2), pp. 151-177. 